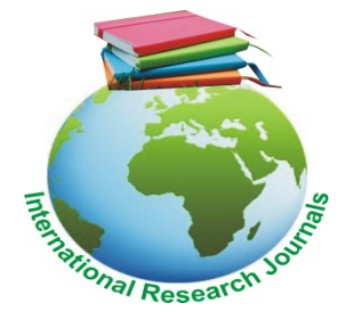

International Research Journal of Agricultural Science and Soil Science (ISSN: 2251-0044) Vol. 6(1) pp. 008-019, April, 2016

Available online http://www.interesjournals.org/IRJAS

DOI: http:/dx.doi.org/10.14303/irjas.2016.016

Copyright (c) 2016 International Research Journals

Full Length Research Paper

\title{
Interaction between the leopard moth borer and olive varieties: Associational resistance at work
}

\author{
${ }^{1}$ Esmat E.H., ${ }^{2}$ Fredrik S., ${ }^{3}$ Wedad K., ${ }^{4}$ Maria K., ${ }^{5}$ Agamy E., ${ }^{6}$ Atwa A. A., ${ }^{7}$ Gadelhak G. \\ ${ }^{1 / 7}$ Department of Economic Entomology, Faculty of Agriculture, Alexandria University, Egypt \\ ${ }^{2}$ Swedish University of Agriculture Sciences, 23053 Alnarp, Sweden \\ ${ }^{3}$ Plant Protection Research Institute, Alexandria, Egypt \\ ${ }^{4}$ Chemical Ecology and Natural Products Laboratory, NCSR "Demokritos", Ag. Paraskevi, 15310, Athens, Greece \\ ${ }^{5}$ Faculty of Agriculture, Cairo University, Cairo, Egypt \\ ${ }^{6}$ Deanship of Scientific Research, King Abdulaziz University, Jeddah, Kingdom of Saudi Arabia.Plant Protection \\ Research Institute, Giza, Egypt \\ Corresponding Author's E-mail: eshegazi@hotmail.com
}

\begin{abstract}
In the last few decades, the population of leopard moth, Zeuzera pyrina L. (Lepidoptera: Cossidae) became high and wide spread in newly established olive orchards in Egypt, where it causes damages and decreases plant vigor. Newly established olive orchards suffered the greatest damage from this woodborer insect, including the death of young trees. In Egypt, damage caused by leopard moth led even to olive grove uprooting. Field data show clear differences in number of active galleries/tree and number of broken olive shoots among olive varieties, while laboratory rearing experiments show strong differences in suitability for larval development. The varietal sensitivity of olive trees, based on a plantation of mixed varieties in ratio of 1:1 in rows of $3+3$ on 900 tree /plot, could be summarized as follows: a. Some olive varieties (2 vrieties/plot) were much less injured (Shamy, Kalamata, and Dolcie) than others (Hamed, Toffahi, and Sennara), showing variation in resistance., b. Development (survival, growth) of artificially infested larvae (no-choice test) within shoots took place successfully only in certain varieties (e.g. Toffahi and Sennara), showing tree resistance to insect feeding, d. Susceptible varieties like Toffahi growing together in a plot with resistant varieties (e.g. Shamy) tended to have lower attack densities, showing Associational Resistance (AR) at work, e. The mechanism(s) of the observed AR are as yet not known, but may include both a strict sense Resistance of some varieties-giving a lower Resource Concentration, and a Semiochemical Diversity - giving reduced search efficiency in pre- or postlanding host selection or possibly habitat selection, or a reduced chemical appearance of the resistant variety.
\end{abstract}

Keywords Zeuzera pyrina, associational resistance, olive varieties, leopard moth

\section{INTRODUCTION}

The leopard moth, Zeuzera pyrina L. (ZP) (Lepidoptera: Cossidae), is a native of Europe. It was first found in the United States in New-Jersey in 1887 (Howard and Chittenden, 1916). It is distributed throughout the western Palearctic region, all over Europe, the Democratic People's Republic of Korea, the Republic of Korea and the United States (Feron et al., 1966). In the eastern Mediterranean, it seriously attacks olive groves in Israel
(Navon, 1977), Lebanon, Syria and Jordan (Katlabi, 1989). In Egypt, $Z P$ is a pest with increasing importance in recently established olive plantation (Ismail et al., 1992; Hegazi et al., 2015). The $Z P$ is a xylophagous species, whose larvae begin boring into the shoots and gradually, as they develop, spread into branches throughout the entire plant, eventually causing the tree to wither and die (Bonnemaison, 1976). It attacks a wide 
variety of trees and shrubs. Over 150 plant species of up to 20 taxonomic genera, such as apple, pear, plum, olive, apricot, chestnut, and vines are attacked (Carter, 1984; Gatwick, 1992). In nurseries or young plantations, the damages could be particularly massive (Castellari, 1986; Tremblay, 1986).

Control of $Z P$ is very problematic because the larvae live inside the branches and the egg laying lasts about 6 months. Alternative control methods have been sought for decades without acceptable practical results: entomopathogenic fungi and bacteria, both natural and commercial, including Bacillus thuringiensis (Myers, 1988; Pasqualini, 1989; Nashnosh et al., 1993), entomopathogenic nematodes (Abdel-Kawy et al., 1992), chitin synthesis inhibitors (Myers, 1988) and pheromones (Pasqualini, 1989; Pasqualini et al., 1992; Nashnosh et al., 1993; Pasqualini et al., 1993; Avilla and Bosh, 2001) are the most extensively studied methods during the last few decades. Current control practices include either manual killing of larvae inside their galleries which is time consuming, labor intensive and therefore a costly procedure, or wide spectrum insecticide applications against adults. However due to the prolonged adult emergence period and the short residual activity of the insecticide sprays, a large number of applications is required throughout the active period of the insect for an effective control.

The dependence on chemical control constitutes a major constrain in the development of IPM strategies, primarily because of resistance problems, detrimental effects on natural control of secondary pests and pesticide residues on fruits (Aramborg, 1983). The sexual pheromone of $Z P$ is known and mass-trapping in pheromone baited traps and/or mating disruption may constitute promising alternative tactics, compatible with IPM strategies (Pasqualini et al., 1996; Pasqualini et al., 1999, Avilla and Bosh, 2001; Hegazi et al., 2009 and 2010).

A considerable number of olive varieties have been identified in different Mediterranean countries, distinguished mainly on the basis of their different morphological characteristics on leaves, flowers and fruits. Sixteen major varieties are reported in Egypt (Tadros and Revri, 2004). Use of insect-resistant varieties is economically, ecologically, and environmentally advantageous. Intercropping is a traditional agricultural technique for reducing crop losses by pathogens and insect infections, especially in the tropics (Theunissen and Den, 1980; Trenbath, 1993). Among the various methods of intercropping commonly practiced, strip cropping has been described as having the greatest potential to increase crop yields by suppressing pest outbreaks (Hickman and Wratten, 1996; Ramert et al., 2002). However, there is a general lack of educational information available to growers as to the understanding of crop varieties, disease severity and management practices (Thresh and Cooter, 2005).

Fortunately, we found an olives orchard with 88 plots where 9 olive varieties were planted with growing system of 2 olive varieties grown concurrently in strips/plot. Cultural methods of control using varietal methods have been relegated to the back ground, and there is a need for additional research before they can be deployed effectively (Thresh and Cooter, 2005). The present study is part of an ongoing project "Allelochemic nonpreference for sustainable control of Zeuzera pyrina in olive farms". The main objective of this study was to determine the effect of varietal diversity of olive trees on crop damage and yield.

\section{MATERIALS AND METHODS}

\section{Site description}

The study was conducted from 2006 to 2010 in a densely planted olive orchard (240 ha, 336 trees/ha) located in the arid growing area between Alexandria and Cairo (177 $\mathrm{km}$ south Alexandria) (E 30 $51^{\prime} 21^{\prime \prime}$; $\left.\mathrm{N} 30^{\circ} 08^{\prime} 27^{\prime \prime}\right)$. The farm is divided into 88 isolated plots (3.0-3.5 ha, each) by windbreak hedges (Casuarina stricta). Each plot is divided into 10 sectors 'strips', each $3 \times \approx 26$ to 30 trees. Each strip combines three lines of one variety alternated by another strip of 3 lines of the second variety and so on "strip cropping system". So the width of each strip is similar.

The orchard has been established in 1996, it is drip irrigated and not in close proximity of apple plantation or any other known host plants of Zeuzera species. Dolce, Sennara, Shami, Manzanillo, Toffahi, Hamed, Kalamata, Picual and Akss are the principal varieties of table olives, constituting approximately $5.3,5.8,4.2,26.1,12.4,4.7$, $8.1,27.2$ and $6.2 \%$, respectively, of the total bearing 61774 olive trees. Trees were approximately 3-4 m height, planted at $5 \mathrm{~m}$ distance along the row and $6 \mathrm{~m}$ distance between rows.

No chemical control was applied on monitoring or experimental plots during the experimental period. During 2006-2009, the mean annual rainfall was $9.2 \mathrm{~mm}$. The rainy seasons last from November-December to JanuaryFebruary. The mean monthly minimum temperature varies from $10.2^{\circ} \mathrm{C}$ in January to $23.9^{\circ} \mathrm{C}$ in August and the mean monthly maximum temperature varies from $18.9^{\circ} \mathrm{C}$ in January to $35.6^{\circ} \mathrm{C}$ in July. The mean relative humidity varies from $47.8 \%$ in April to $63.8 \%$ in January.

\section{Flight dynamics of Z. pyrina}

The seasonal flight activity of both sexes of the pest was monitored for two consecutive years (2006 and 2007) by the UV- light -pheromone trap type (Hegazi et al., 2009). Five, 3 ha plot with bad history of $Z P$ infestation were selected. Five adhesive traps were installed (1/plot). Each was baited with pheromone dispensers [FERSEX ZP C TM, Sociedad Española de Desarrollos Quimicos 
(SEDQ), Barcelona, Spain]. The dispensers were polyethylene containers loaded each with $10 \mathrm{mg}$ of $Z$. pyrina pheromone; 95\% (E, Z)-2,13-octadecenyl acetate and $5 \% \quad(E, \quad Z)-3,13-o c t a d e c e n y l$ acetate (SEDQ, Barcelona, Spain). The first three traps were installed in the centre of the plot while the fourth and fifth were near the edge zone of the other plots. Each trap was mounted on top of a wooden-metal pole and its height was adjusted to $50-100 \mathrm{~cm}$ above the canopy level. Trap light was turned on from sunset to sunrise. Distance between traps was no less than $200 \mathrm{~m}$. Monitoring was initiated on the last week of April and ended on the second week of November. Traps were checked every other day to prevent build up of target and non-target insects, which can affect trapping efficiency. The weekly mean capture of $Z$. pyrina moths was recorded. Pheromone dispensers were replaced every 40 days.

\section{Methods of measuring $Z$. pyrina-Resistant olive varieties}

\section{Detection strategies of $Z P$ infestation}

Infestations were recognized by the presence of insect's frass around the entrance of larval tunnels. Protruding empty pupal skins are often observed indicating emergence of moths. Infested branches easily break due to fruit load, wind or mechanical damage. Also, infested trees react by secreting gum. Yellowish to brown excretions could be observed in bark crevices and on the ground underneath the infested tree. Infestation severity is measured by percentage of tree infested.

\section{Number of active galleries/tree}

Twelve olive plots ( 3 ha each ,2 varieties /plot) with $Z P$ infestation were selected, to study the interaction of $Z P$ to different olive varieties for two successive years (2007 "of year" and 2008 "on year ", respectively.

All trees in each strip $(\approx 90$ trees/strip) of nine plots (2007) and 12 plots (2008) were inspected every other week for new damage assessment from August 1 through October 30 for both seasons. In each inspection, the cumulative number of active galleries with larvae or pupae was recorded and marked, and the tree was classified as infested or non-infested.

\section{Number of broken branches due to fruit load}

The insect larva bores into the branches and feeds upon the living wood. The larva usually begins burrowing in twigs and small branches and trunks; its feeding action weakens the wood that the part following infestation injury is often broken by wind and fruit load. Eight, 3 ha plots were selected in 2009. Thirty randomly selected trees $\times 10$ replicates/ variety were inspected each other week. Inspection was carried out from July to September for green table olives (Sennara, Shamy, Manzanillo, Toffahi, Hamed, and Akss) and from August to October for black table olives Dolce (Picual and Kalamata) to record cumulative number of broken branches in bearing /tree/variety.

\section{Suitability of olive variety for larval growth of the leopard moth}

Four olive varieties were selected in 2009 for this study. We believed that they span the range of suitable and non-suitable hosts. Our previous studies suggested Toffahi and Sennara were highly suitable for ZP larvae and Dolcie and Kalamata were non-suitable. Healthy branches were selected from 1-2 trees/variety, and were cut $(30 \times 3 \mathrm{~cm})$. A $1 \times 3 \mathrm{~cm}$ hole was drilled into the distal end of each branch. To keep the caterpillar's food plant fresh, the bases of food plants were placed in a small jar of water. Then the larvae were gently introduced singly in the drilled holes, and held in place. All the test larvae were originated from Toffahi infested trees. Larvae were weighed (accuracy $+10^{-4}$ ). To normalize for variation in initial weight, smaller larvae than those of the fifth instar $(\approx 0.635 \mathrm{~g})$, were reared on diet based on kidney beans (kidney beans, whole milk powder, sucrose, olive oil, ascorbic acid, agar, methyl-p-hydroxylbenzoate, olive branches powder (Toffahi variety), L-chloramphenicol, medical dried yeast, formaldehyde and water) till reaching the desired weight. The larvae were singly reared until their emergence as pupae from infested food plant. Some life characteristics of $Z P$ were carefully taken for comparison.

\section{Statistical analysis}

Percentage values were subjected to arcsine square root transformation to increase the homogeneity of variance and normality. Data were analyzed by one-way analysis of variance (ANOVA) and means were compared by least significant difference (LSD) or Student's t-test. The SPSS 8.0 software (SPSS Inc., Chicago, IL) was used for statistical analyses.

\section{RESULTS}

\section{Trap catches}

Although our major concern of the present work was to screen nine olive varieties in different cropping systems for Zeuzera - resistant olive varieties, before this objective could be realized it was necessary to monitor the flight phenology of this pest. In 2006 and 2007, we monitored the season-long presence of leopard moth in 
five 3-ha olive plots by using light trap Hegazi model (Hegazi et al., 2009) baited with sex pheromone to understand the fluctuation of this pest's population in the olive orchard (Fig. 1). In 2006, the traps caught low numbers in May then the catches progressively increased in August and September reaching two peaks on August 23rd (12.5 $\pm 3.9 /$ trap/week) and September 20th (15.9 $\pm 2.0 /$ trap/week). In 2007, the first leopard moth occurred during the last week of April. Captures of ZP occurred continuously from April throughout the growing season until the second week of November, i.e., moths were present all season. Mass flight was recorded in August-October, with a clear peak on 22 September (22.5 $\pm 3.8 /$ trap/week). During the whole trapping seasons of all trapped leopard moths (120.5 and 218 moths per trap, in 2006 (high fruiting year) and 2007 (low fruiting year), respectively, only 4.2 and $8.8 \%$ were females, respectively. In 2006, no females were captured from May to mid-June. In general, ZP catches were greatest in the August-October period. Of total trap catches in 2006, $62.9 \%$ moths were caught during this period versus $77.9 \%$ in 2007.

The effects of olive variety on leopard moth incidence were investigated by comparing: (1) the infestation severity and cumulative active larval galleries of ZP during the peak period of adult emergence on different strips of olive plots; (2) cumulative number of broken branches in bearing near harvesting period on different varieties of olive trees and (3) suitability of some olive varieties for larval growth of $\mathrm{ZP}$.

\section{Effect of crop-crop diversity on infestation severity and amount of active larval galleries}

In 2007 (low yield fruit season) and 2008 (high yield fruit season), comparative trials testing nine olive varieties on different strip cropping systems for $Z P$ infestation were performed (Table 1). The data on the percent infestation of $Z P$ on olive trees for different cropping systems revealed that infestation was the highest when Hamed + Sennara or Sennara + Toffahi were planted together, than when each was grown with different accompanying variety. Low ZP infestation was observed on cropping system "plots" included varities namely Picual + Manzanello, Akass + Toffahi, Shami + Toffahi and Dolcie + Kalamata. Akass or Shami as a companion olive variety affected the infection rate of $Z P$ on the other associated variety, e.g., Sennara and Toffahi. Of the total active larval galleries recorded in $2007,70 \%$ were recorded on only two cropping system (plots included three olive varieties) namely Hamed + Sennara and Sennara + Toffahi (Table 1) versus $56.0 \%$ on the same cropping systems in 2008.

When ZP larva fully matures it transforms to pupa within its burrow. When the moth emerges, the empty pupal skin remains for some time projecting from the larval tunnel. Table 1 shows the data of the percentage of pupal skins observed. The results suggest more $Z P$ pupal skins were found on Hamed, Sennara and Toffahi varieties than others.

Figure 2 shows mean number of cumulative active $Z P$ galleries/ tree of nine olive varieties. The differences among these varieties were highly significant $(F=7.1, d f=$ $8,36, \mathrm{P}<0.01)$. From the largest number to the smallest, the resulting ranking was Hamed, Toffahi, Sennara, Dolcie, Shami, Manzanello, Picual, Kalamata and Akass. Also, ZP infestation severity was highest on Toffahi $(61.3 \%)$ versus ca. $3 \%$ on Akass, Manzanello, Picual and Kalamata. The data on the mean number of active $Z P$ galleries for different cropping systems are shown in Figure. 3. Minimum number of $Z P$ galleries were observed when Toffahi was strip planted with Shami or Akass which differed significantly when Toffahi was grown with Sennara variety $(F=9.2, d f=5,24, P<0.01)$.

As shown in Figure. 4, when Hamed or Toffahi variety acted as companion to Sennara variety the population of larval galleries was high on the Sennara trees. However, the differences among strips were statistically nonsignificant. Generally, similar results were obtained in 2009 season (Figure. 5). The incidence of larval galleries differed significantly among olive varieties $(F=30.7$, df $=$ $7,32, P<0.05$ ). From the highest to the lowest incidence of larval galleries, the resulting ranking was Toffahi, Sennara, Hamed, Picual, Kalamata, Manzanillo, Dolcie, Shami, and Akass. Figure 6 shows the effects of strip cropping systems on the incidence of $Z P$ larval galleries on Toffahi trees. Sennara as a companion variety with Toffahi showed significantly higher incidence of larval galleries compared with other olive varieties $(F=3.7, d f=$ $7,32, \mathrm{P}<0.05)$.

\section{Effects of crop-crop diversity on number of broken branches}

The ZP larva bores into the branches of olive trees and feeds upon the living tissue. The earliest symptoms may be broken twigs and branches with yellow and wilted foliage. Larval tunnels in the wood and burrows under the bark are visible at the ends of broken limbs. Only the numbers of broken branches were counted cumulatively during fruit ripening period of olive fruits. In 2009 olive season, the number of broken branches in bearing were counted and categorized into 3 groups, trees with 1 to 3 and those of 4 to 6 and the last of $\geq 7$ broken limbs/ tree. Trees with 7 or more broken limbs in bearing are characteristic of heavy infestations by ZP Larvae. Table 2 summarizes the data of infestation severity, cumulative number of broken branches and fruit weight "loss" on the broken twigs and branches on eight plots of different strip cropping patterns. The results suggested that olive trees of some strip cropping systems, e.g., Sennara + Toffahi and Hamed + Sennara were severely injured by the $Z P$ larvae. The total counts of broken branches in bearing among nine olive varieties are shown in Figure. 7 . There 
012 Int. Res. J. Agric. Sci. Soil Sci.

Table 1 Infestation rate (\%) and total number of cumulative larval galleries Zeuzera pyrina / olive variety in plots of different strip cropping systems between August 1 and late October in 2007 and 2008 olive seasons.

\begin{tabular}{|c|c|c|c|c|c|c|c|c|c|c|c|}
\hline \multirow{3}{*}{ Plot } & \multirow{3}{*}{ Olive variety } & \multirow{3}{*}{$\begin{array}{l}\text { Trees } \\
\text { No. }\end{array}$} & \multirow{2}{*}{\multicolumn{4}{|c|}{$\begin{array}{c}2007 \text { Season } \\
\text { Active galleries }\end{array}$}} & \multirow{2}{*}{\multicolumn{4}{|c|}{$\begin{array}{c}2008 \text { Season } \\
\text { Active galleries }\end{array}$}} & \multirow{3}{*}{ Notes } \\
\hline & & & & & & & & & & & \\
\hline & & & $\begin{array}{l}\text { Infest } \\
(\%)\end{array}$ & $\begin{array}{l}\text { Total } \\
\text { (No.) }\end{array}$ & $\begin{array}{c}\text { Pupal Skin } \\
(\%)\end{array}$ & $\begin{array}{l}\text { No.l } \\
\text { Tree }\end{array}$ & $\begin{array}{l}\text { Infest } \\
(\%)\end{array}$ & $\begin{array}{l}\text { Total } \\
\text { (No.) }\end{array}$ & $\begin{array}{l}\text { Pupal Skin } \\
(\%)\end{array}$ & $\begin{array}{l}\text { No.l } \\
\text { Tree }\end{array}$ & \\
\hline \multirow[b]{2}{*}{1} & Hamed & 522 & 30.4 & 1194 & 36.4 & 2.3 & 7.8 & 167 & 39.5 & 0.3 & \multirow{2}{*}{$\begin{array}{c}\text { In 2007, mass- } \\
\text { trapping + manual } \\
\text { killing }\end{array}$} \\
\hline & Sennara & 435 & 23.4 & 644 & 48.3 & 1.5 & 6.4 & 121 & 45.6 & 0.3 & \\
\hline \multirow{2}{*}{2} & Sennara & 390 & 41.7 & 710 & 8.5 & 1.8 & 41.3 & 970 & 25.8 & 2.5 & \multirow{2}{*}{$\begin{array}{l}\text { Neighbouring trees } \\
\text { Toffahi and Hamed }\end{array}$} \\
\hline & Toffahi & 390 & 61.3 & 998 & 15.7 & 2.5 & 41.5 & 810 & 32.1 & 2.1 & \\
\hline \multirow{2}{*}{3} & Sennara & 390 & 32.6 & 425 & 12.5 & 1.1 & 35.9 & 693 & 27.1 & 1.8 & \multirow{2}{*}{$\begin{array}{c}\text { Neighbouring trees } \\
\text { Toffahi }\end{array}$} \\
\hline & Toffahi & 390 & 30.5 & 838 & 20.7 & 2.1 & 34.4 & 938 & 34.3 & 2.5 & \\
\hline \multirow{2}{*}{4} & Shami & 435 & 8.0 & 133 & 6.0 & 0.3 & 5.5 & 125 & 1.6 & 0.2 & \multirow{2}{*}{$\begin{array}{l}\text { Neighbouring trees } \\
\text { Shami and Akss }\end{array}$} \\
\hline & Toffahi & 435 & 22.0 & 240 & 7.5 & 0.3 & 16.6 & 315 & 35.1 & 0.7 & \\
\hline \multirow{2}{*}{5} & Akss & 420 & 3.7 & 19 & 10.5 & 0.05 & 2.1 & 54 & 2.1 & 0.1 & \multirow{2}{*}{$\begin{array}{l}\text { Neighbouring trees } \\
\text { Toffahi and Shami }\end{array}$} \\
\hline & Toffahi & 420 & 15.5 & 248 & 5.4 & 0.6 & 9.5 & 219 & 16.1 & 0.5 & \\
\hline \multirow[b]{2}{*}{6} & Shami & 435 & 11.9 & 50 & 6.0 & 0.1 & 3.9 & 46 & 13.0 & 0.1 & \multirow{2}{*}{$\begin{array}{c}\text { Neighbouring trees } \\
\text { Picual and } \\
\text { Manzanello }\end{array}$} \\
\hline & Toffahi & 435 & 14.0 & 191 & 6.3 & 0.4 & 9.8 & 287 & 25.4 & 0.7 & \\
\hline \multirow{2}{*}{7} & Shami & 435 & 7.1 & 112 & 14.3 & 0.2 & 1.6 & 42 & 7.1 & 0.1 & \multirow{2}{*}{$\begin{array}{l}\text { Neighbouring trees } \\
\text { Shami and Toffahi }\end{array}$} \\
\hline & Toffahi & 435 & 8.3 & 259 & 19.3 & 0.5 & 6.6 & 250 & 20.0 & 0.5 & \\
\hline \multirow{2}{*}{8} & Dolcie & 405 & 12.1 & 191 & 5.2 & 0.5 & 21.2 & 233 & 17.2 & 0.5 & \multirow{2}{*}{$\begin{array}{c}\text { Neighbouring trees } \\
\text { Toffahi }\end{array}$} \\
\hline & Kalamata & 405 & 9.3 & 109 & 2.7 & 0.3 & 23.9 & 249 & 19.6 & 0.6 & \\
\hline \multirow{2}{*}{9} & Dolcie & 435 & 14.2 & 155 & 11.6 & 0.3 & 14.1 & 300 & 13.3 & 0.6 & \multirow{2}{*}{$\begin{array}{c}\text { Neighbouring trees } \\
\text { Toffahi }\end{array}$} \\
\hline & Kalamata & 435 & 14.4 & 153 & 0.6 & 0.3 & 18.3 & 370 & 13.5 & 0.8 & \\
\hline \multirow{2}{*}{10} & Picual & 420 & 4.3 & 102 & 15.1 & 0.2 & --- & --- & --- & --- & \multirow{2}{*}{$\begin{array}{l}\text { Neighbouring trees } \\
\text { Akss and Toffahi }\end{array}$} \\
\hline & Manzanello & 420 & 5.4 & 93 & 13.1 & 0.2 & --- & --- & -- & --- & \\
\hline \multirow{2}{*}{11} & Shami & 435 & --- & -- & -- & -- & 0.7 & 9.0 & 11.1 & 0.1 & \multirow{2}{*}{$\begin{array}{l}\text { Neighbouring trees } \\
\text { Akss and Toffahi }\end{array}$} \\
\hline & Toffahi & 435 & --- & --- & --- & --- & 3.4 & 106 & 14.1 & 0.2 & \\
\hline \multirow{2}{*}{12} & Akss & 450 & --- & --- & --- & --- & 1.3 & 14 & 7.1 & 0.1 & Neighbouring trees \\
\hline & Toffahi & 450 & --- & --- & --- & --- & 6.6 & 160 & 11.8 & 0.2 & Shami and Toffahi \\
\hline 13 & Picual & 375 & -- & -- & --- & --- & 6.9 & 90 & 11.1 & 0.2 & Neighbouring trees \\
\hline & Manzanello & 325 & --- & --- & --- & --- & 3.2 & 27 & 11.1 & 0.1 & Akss and Toffahi \\
\hline
\end{tabular}

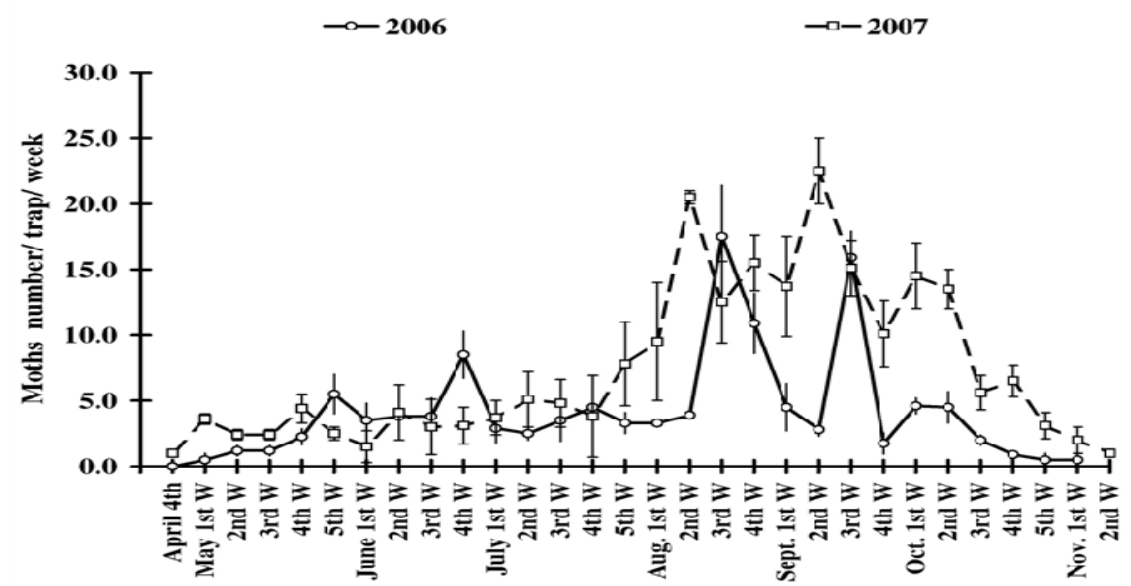

Figure. 1 Weekly mean number of Zeuzera pyrina moths/ trap. Vertical bars represent mean $\pm S D$.

were significant differences among the olive varieties ( $F=$ 75.2, $\mathrm{df}=8,81, \mathrm{P}<0.05$ ). From the largest number of broken limbs to the smallest, the resulting ordering was
Toffahi, Sennara, Hamed, Picual, Manzanello, Kalamata, Dolcie, Akss and Shami. The effect of strip cropping pattern on abundance of broken branches caused by ZP 
Esmat et al. 013
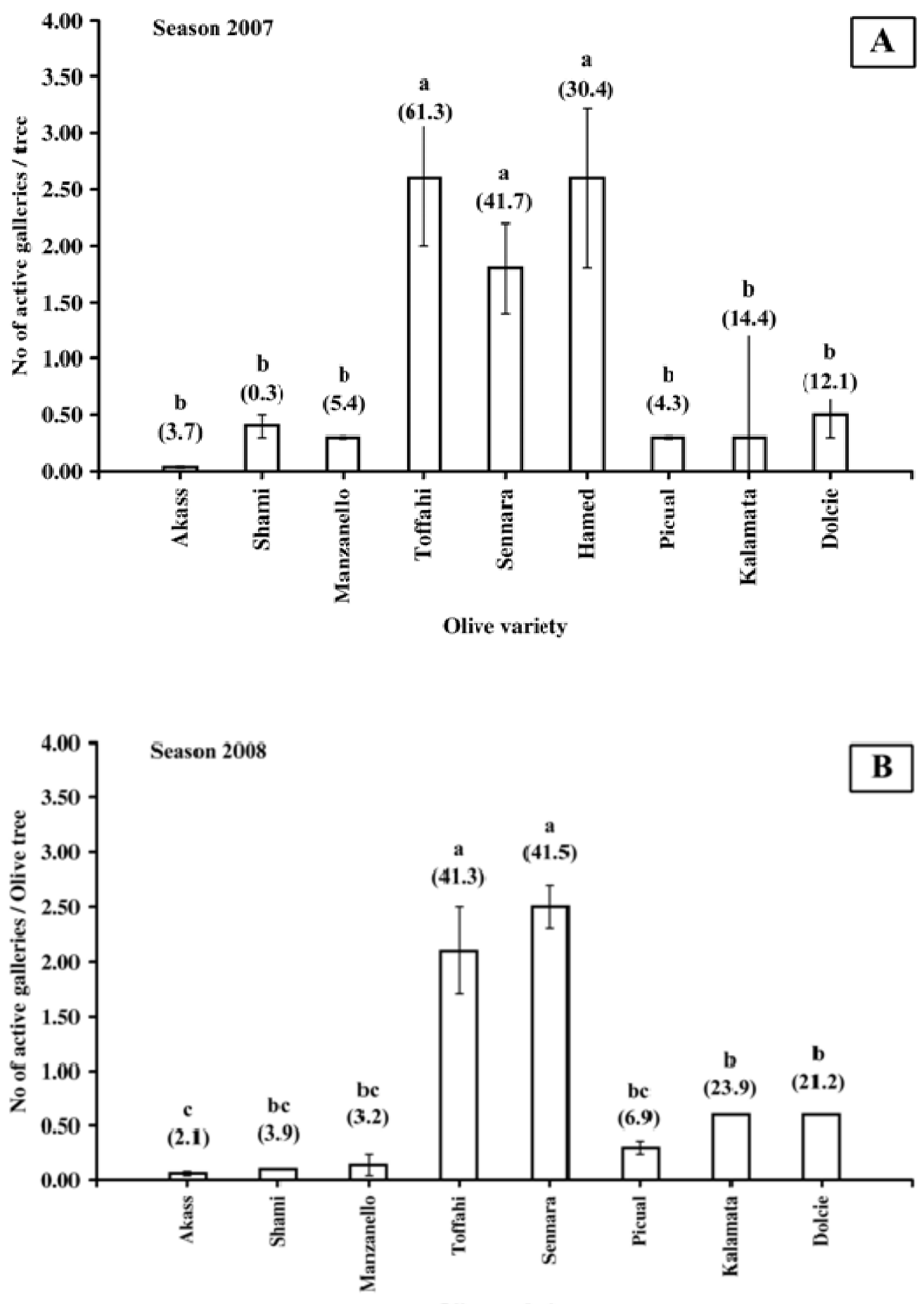

Olive varieties

Figure. 2 Number (mean $\pm S E$ ) of cumulative active Zeuzera pyrina galleries/ tree of different olive varieties. The number in brackets refer to percentage of infested tree/ plot. Bars headed by different letters are significantly different by least significant difference (for 2007: LSD= 1.5 at $\mathrm{P}<0.01$, for 2008: $L S D=0.4$ at $\mathrm{P}<0.05$ ).

larvae "infestation severity" is shown in Figure 8. The data on the number of broken branches on Toffahi trees (susceptible variety) under three cropping patterns including resistant (Shami and Akass) and other susceptible (Sennara) varieties are shown in Figure 8. There were highly significant differences in number of 
014 Int. Res. J. Agric. Sci. Soil Sci.
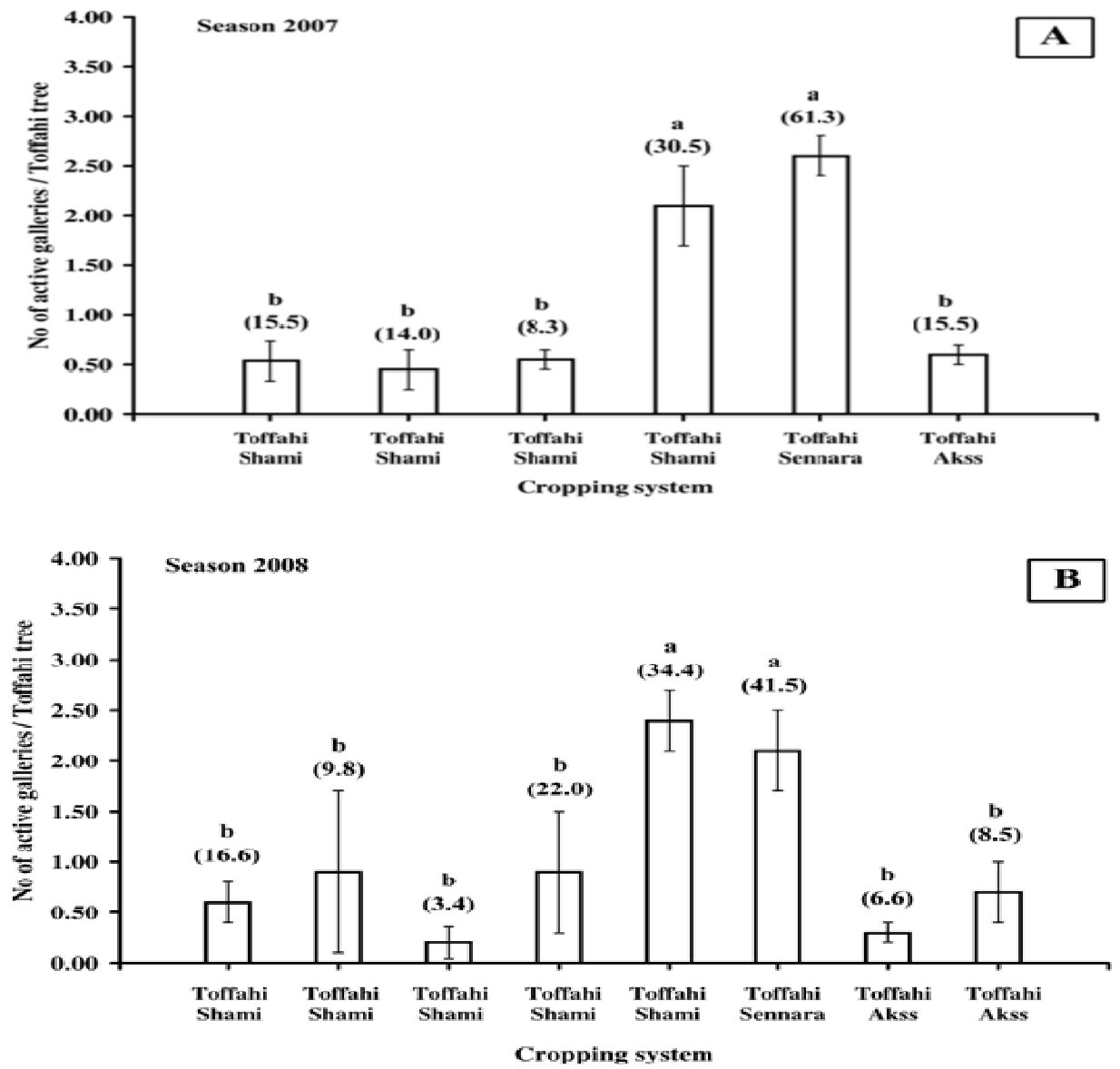

Figure 3: Number (mean $\pm S E$ ) of cumulative active Zeuzera pyrina galleries per Toffahi tree in different cropping systems"plots". The number in brackets refers to percentage of infested tree. Bars headed by different letters are significantly different by least significant difference (for 2007: $L S D=1.25$ at $P<0.01$, for 2008: $L S D=1.1$ at $P<0.05$ ).

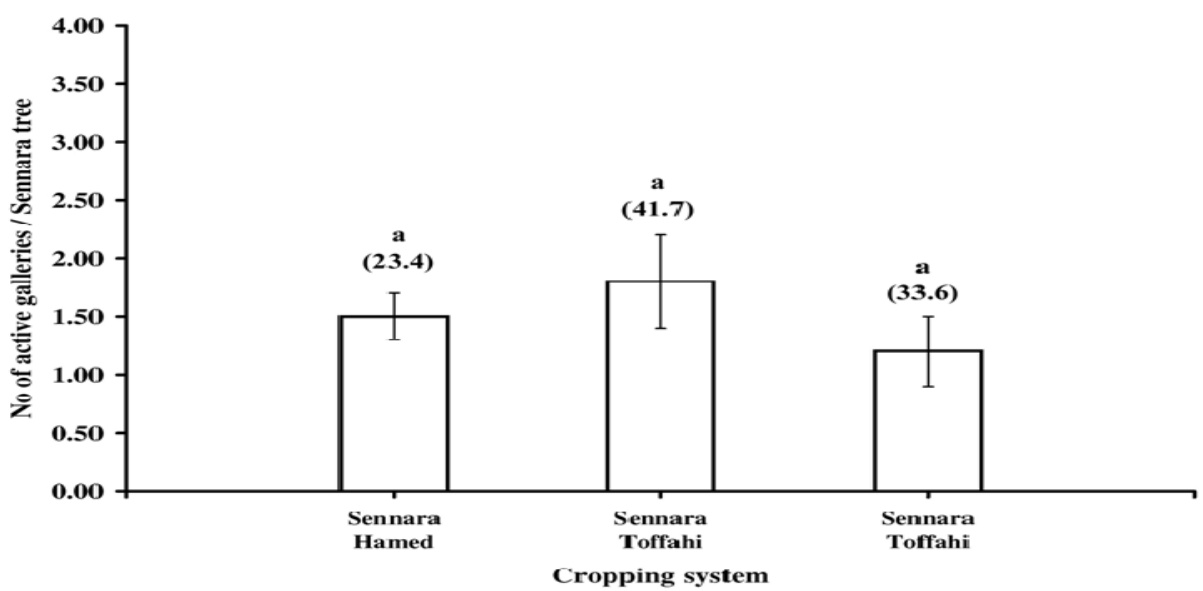

Figure 4: Number (mean \pm SE) of cumulative active Zeuzera pyrina galleries per Sennara tree in different cropping systems "plots"in 2007 season. The number in brackets refers to percentage of infested Sennara tree per plot. Bars headed by the same letters are not significantly different. 


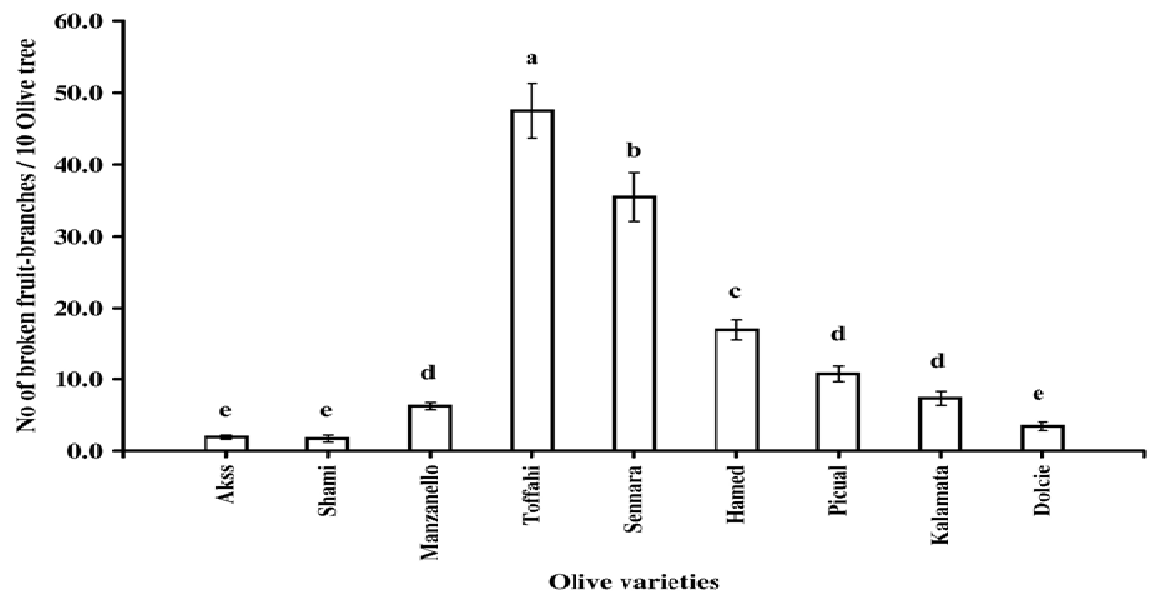

Fig. 5 Number (mean \pm SE) of broken branches/ olive tree/ variety in 2009 season. Bars headed by different letters are significantly different by least significant difference $(L S D=5.2$ at $P<0.05)$.

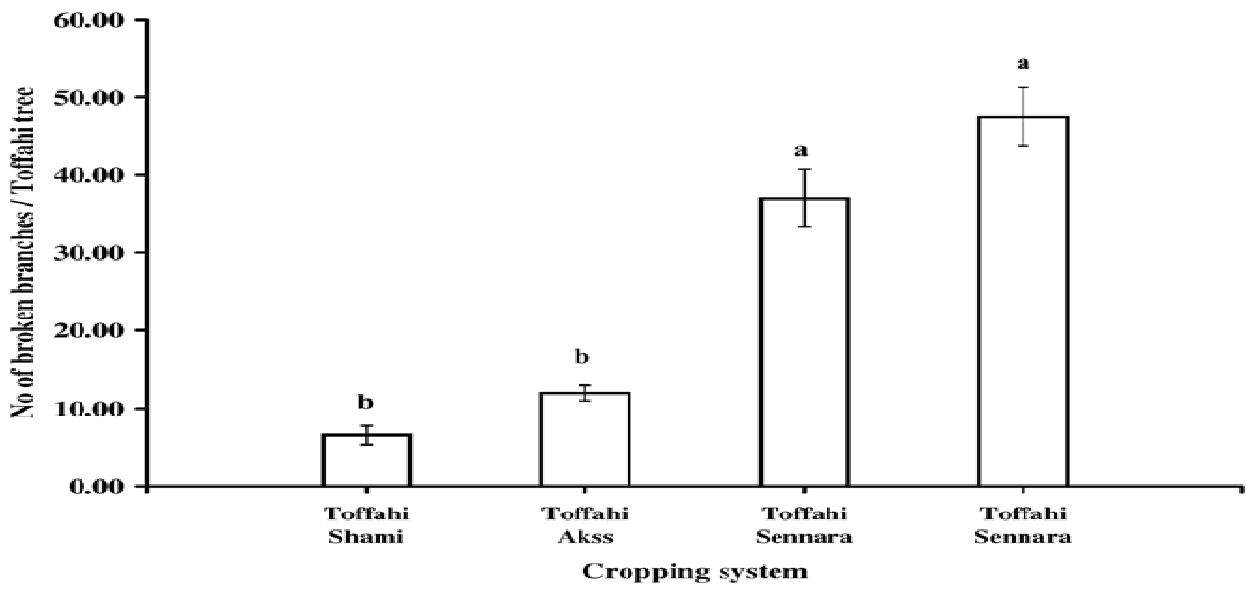

Figure 6: Number (mean $\pm S E$ ) of broken limbs/ Toffahi tree on different cropping systems"plots) in 2009 season. Bars bearing different letters are significantly different by least significant difference $(\mathrm{LSD}=10.6$ at $\mathrm{P}<0.01)$

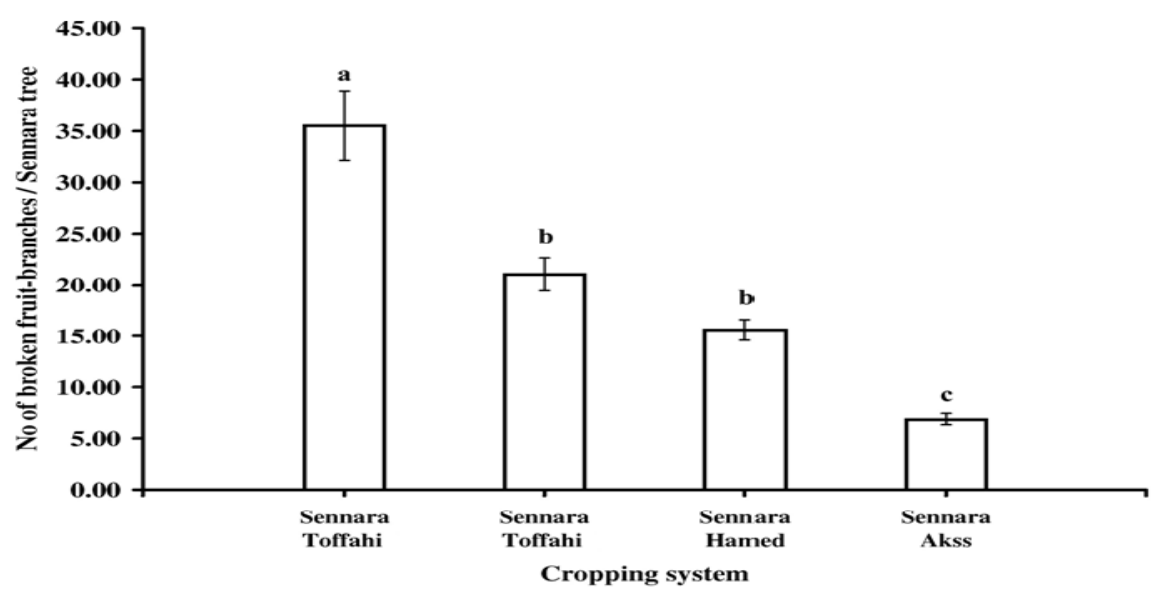

Figure 7: Number (mean \pm SE) of broken limbs/ Sennara tree on different cropping systems "plots" in 2009 season. Bars headed by different letters are significantly different by least significant difference $(\mathrm{LSD}=7.5$ at $\mathrm{P}<0.01)$. 
016 Int. Res. J. Agric. Sci. Soil Sci.

Table 2: Infestation severity and cumulative number of broken branches in bearing among 300 trees/ variety (30 tree $\times 10$ replicate) on different cropping systems (plots) and weight of olive fruits (Kg) on broken branches, (2009 season).

\begin{tabular}{|c|c|c|c|c|c|c|c|}
\hline \multirow{3}{*}{\multicolumn{2}{|c|}{ Plot: variety }} & \multirow{4}{*}{$\begin{array}{c}\begin{array}{c}\text { Infestation } \\
\text { severity (\%) }\end{array} \\
52.3\end{array}$} & \multicolumn{4}{|c|}{ Broken limbs in bearing } & \multirow{4}{*}{$\begin{array}{c}\begin{array}{c}\text { Fruit loss } \\
\text { (Kg) }\end{array} \\
1339\end{array}$} \\
\hline & & & \multirow{3}{*}{$\begin{array}{c}\text { Total (No.) } \\
475(157)\end{array}$} & \multicolumn{3}{|c|}{ Frequency/ tree } & \\
\hline & & & & 1-3 limbs & 4-6 limbs & $\geq 7$ limbs & \\
\hline \multirow{2}{*}{1} & Toffahi & & & 70.0 & 17.8 & 12.1 & \\
\hline & Sennara & 37.3 & $355(113)$ & 75.0 & 11.5 & 13.3 & 963 \\
\hline \multirow{2}{*}{2} & Toffahi & 40.0 & $370(120)$ & 67.5 & 20.0 & 12.5 & 1046 \\
\hline & Sennara & 30.0 & $210(90)$ & 80.0 & 15.5 & 4.4 & 660.2 \\
\hline \multirow{2}{*}{3} & Toffahi & 12.6 & $120(38)$ & 65.8 & 21.1 & 13.1 & 336 \\
\hline & Akss & 5.3 & $31(16)$ & 81.2 & 18.75 & 0.0 & 206 \\
\hline \multirow{2}{*}{4} & Toffahi & 6.6 & $65(20)$ & 65.0 & 20.0 & 15.0 & 179 \\
\hline & Shami & 2.6 & $17(8)$ & 75.0 & 25.0 & 0.0 & 46 \\
\hline \multirow{2}{*}{5} & Picual & 15.0 & $107(45)$ & 80.0 & 13.3 & 6.6 & 500 \\
\hline & Manzanello & 13.0 & $82(39)$ & 79.5 & 20.1 & 0.0 & 316 \\
\hline \multirow{2}{*}{6} & Dolci & 6.6 & $34(20)$ & 90.0 & 10.0 & 0.0 & 284 \\
\hline & Kalamata & 10.0 & $73(30)$ & 73.3 & 16.6 & 10.0 & 379 \\
\hline \multirow{3}{*}{7} & Hamed & 54.4 & $170(163)$ & 59.0 & 25.5 & 15.5 & 1301 \\
\hline & Sennara & 46.4 & 156(139) & 72.1 & 21.5 & 6.4 & 865.1 \\
\hline & Akss & 3.0 & $19(9)$ & 77.7 & 22.2 & 0.0 & 124 \\
\hline 8 & Sennara & 11.0 & $69(33)$ & 84.8 & 12.1 & 3.0 & 258 \\
\hline
\end{tabular}

The number in brackets refer to number of trees with broken branches

Table 3: Rough estimation of reduction in Z. pyrina population under field condition

\begin{tabular}{lcccccc}
\hline Rep. & $\begin{array}{c}\text { Signs of } \\
\text { attack (No.) } \\
\mathbf{2 0 0 9}\end{array}$ & $\begin{array}{c}\text { No. of active } \\
\text { galleries } \\
\mathbf{2 0 1 0}\end{array}$ & $\begin{array}{c}\text { Possible } \\
\text { reduction } \\
\text { (\%) }\end{array}$ & $\begin{array}{c}\text { Signs of } \\
\text { attack (No.) } \\
\mathbf{2 0 0 9}\end{array}$ & $\begin{array}{c}\text { Shami } \\
\text { Nof active } \\
\text { galleries } \\
\mathbf{2 0 1 0}\end{array}$ & $\begin{array}{c}\text { Possible } \\
\text { reduction } \\
\text { (\%) }\end{array}$ \\
\cline { 2 - 7 } 1 & 995 & 33 & 96.5 & 228 & 6 & 97.3 \\
2 & 1282 & 64 & 95.0 & 264 & 3 & 98.8 \\
3 & 1035 & 25 & 97.5 & 209 & 5 & 97.6 \\
4 & 606 & 41 & 93.2 & 177 & 2 & 98.8 \\
5 & 1059 & 28 & 97.3 & 198 & 1 & 99.1 \\
Mean $\pm S D$ & $995.4 \pm 109.4$ & $38.2 \pm 6.99$ & $95.9 \pm 0.8$ & $215.2 \pm 14.7$ & $3.4 \pm 0.9$ & $98.3 \pm 0.4$ \\
\hline
\end{tabular}

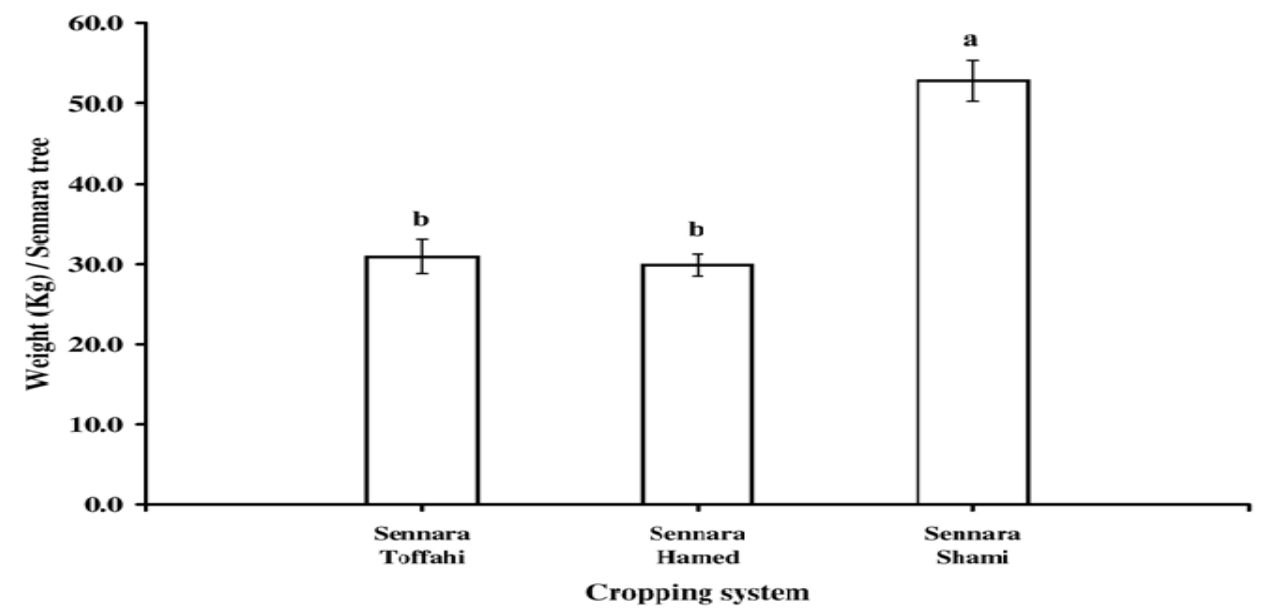

Figure 8: Fruit yield per Sennara tree $(\mathrm{Kg} \pm \mathrm{SE})$ on three cropping systems "plots" in 2009 season. Bars with the same letter are not significantly different by least significant difference $(\mathrm{LSD}=7.5$ at $\mathrm{P}<0.01)$.

variety (susceptible) when grown between another susceptible (Toffahi or Hamed) or ZP-resistant variety
(Akass). The abundance of broken branches was significantly higher in cropping pattern included two 
Table 4: Pupal weight and some life characteristics of $Z$. pyrina originating from deferent larval rearing on living woods of different varieties (2009 season).

\begin{tabular}{|c|c|c|c|c|c|c|c|}
\hline \multirow{3}{*}{$\begin{array}{l}\text { Larvae } \\
\text { No.* }\end{array}$} & \multicolumn{3}{|c|}{ Resulted pupae } & \multicolumn{3}{|c|}{ Adult emergence } & \multirow{3}{*}{$\begin{array}{c}\text { Total } \\
\text { mortality } \\
\text { (\%) }\end{array}$} \\
\hline & \multirow{2}{*}{ No. } & \multicolumn{2}{|c|}{ Wt. (g) } & \multirow{2}{*}{ No. } & \multicolumn{2}{|c|}{$\%$} & \\
\hline & & Male & Female & & Male & Female & \\
\hline & & & & Toffahi & & & \\
\hline 8 & 7 & 1.232 & 1.923 & 7 & 57.1 & 42.8 & 12.5 \\
\hline 8 & 7 & 1.119 & 2.101 & 7 & 71.4 & 28.5 & 12.5 \\
\hline 7 & 6 & 1.510 & 1.819 & 6 & 50.0 & 50.0 & 14.2 \\
\hline \multirow[t]{2}{*}{9} & 8 & 1.229 & 2.001 & 7 & 57.1 & 42.8 & 22.2 \\
\hline & & & & Sennara & & & \\
\hline 9 & 9 & 1.231 & 1.867 & 9 & 66.6 & 33.3 & 0.0 \\
\hline 10 & 9 & 1.316 & 1.887 & 8 & 62.5 & 37.5 & 20.0 \\
\hline 8 & 7 & 1.561 & 1.9110 & 6 & 33.3 & 66.6 & 25.0 \\
\hline \multirow[t]{2}{*}{7} & 6 & 1.671 & 1.532 & 5 & 80.0 & 20.0 & 28.5 \\
\hline & & & & Kalamata & & & \\
\hline 10 & 6 & 0.747 & 0.918 & 6 & 83.3 & 16.6 & 40.0 \\
\hline 10 & 7 & 0.657 & 0.818 & 7 & 42.8 & 57.1 & 30.0 \\
\hline 11 & 6 & 0.701 & 0.998 & 5 & 80.0 & 20.0 & 54.5 \\
\hline \multirow[t]{2}{*}{9} & 4 & 0.821 & 0.0 & 4 & 100.0 & 0.0 & 55.5 \\
\hline & & & & Dolcie & & & \\
\hline 7 & 6 & 0.642 & 1.009 & 4 & 50.0 & 50.0 & 42.8 \\
\hline 9 & 5 & 0.432 & 0.612 & 5 & 60.0 & 40.0 & 44.4 \\
\hline 10 & 7 & 0.399 & 0.0 & 5 & 100.0 & 0.0 & 50.0 \\
\hline 8 & 4 & 0.871 & 0.0 & 3 & 100.0 & 0.0 & 62.5 \\
\hline
\end{tabular}

* Width of the head capsule $=1.8$ to $2.0 \mathrm{~mm}=5^{\text {th }}$ instar $=\approx 0.635 \mathrm{~g}$.

susceptible varieties compared with those cropping pattern including one susceptible and one ZP-resistant variety $(F=37.1, \mathrm{df}=3,36, \mathrm{LSD}=7.5, \mathrm{P}<0.01)$.

Statistical analysis using loss (in $\mathrm{Kg}$ ) of fruit on limbs that broke following the physical weakening by $Z P$-larvae was not good parameters for comparison between the effects of cropping pattern on infestation severity of $Z P$. Therefore, it was omitted.

\section{Effect of cropping system on fruit yield}

A significant effect of cropping system on yield of olive trees was found. The susceptible variety Sennara planted in strip intercropping with ZP-resistance variety showed significantly higher yield when compared with susceptible companion varieties $(F=37.6, d f=2,12, P<0.01)$. The fruit yield of Sennara tree produced $52.8 \pm 2.6,29.9 \pm 1.4$ and $30.9 \pm 2.1 \mathrm{Kg} /$ tree under the cropping pattern of Sennara + Shami, Sennara + Hamed and Sennara + Toffahi, respectively.

\section{Suitability of olive varieties for ZP development}

The pupal weight gain and mortality of $Z P$ among trees of four olive varieties showed considerable variation (Table 4). Slower growth was observed for $Z P$ larvae originating from Toffahi trees and reared on either Kalamata or Dolcie. ZP larvae were usually found deep in the heartwood of Toffahi compared with other test varieties.
Our study suggests that Toffahi trees are more suitable for larval growth than other olive varieties.

In 2009 , the density of $Z P$ moth was generally higher than the any year before "outbreak". On October $25^{\text {th }}$ some of susceptible trees were heavily infested. An olive plot with cropping pattern of Toffahi + Shami was selected. Relatively heavy population of small larvae showed signs of attack. A careful examination of the branches of an infected tree showed a slight amount of powdery sawdust expelled by ZP larvae. The entry holes of the larvae were marked by small heaps of saw-dust and frass. The entry holes of five trees of each variety were carefully recorded and marked. In 2010, the cumulative counts of larval galleries of $Z P$ moths of the same trees between July and late October were recorded (Table 4). The results suggested that more eggs were deposited on susceptible tree (Toffahi) than ZP-resistant tree (Shami) $(t=7.1, P<0.05)$. In both cases, it seems that more than $90 \%$ of $Z P$ larvae suffer mortality. Mortality was significantly higher on Shami trees $(t=2.7, P<0.05)$, compared with those on Toffahi trees.

\section{DISCUSSION}

Trap catches suggest that the leopard moth has a long flight period. Moths were present in all seasons during the study period (2006-2009). Adults appear from the end of April until the second week of November. This wide flight period and the cryptic behavior of the larva make chemical control almost impossible. The distinct flight activity period in August-September indicates the 
018 Int. Res. J. Agric. Sci. Soil Sci.

presence of one generation per olive season. During the monitoring period, the total captures of leopard moths varied according the olive season. The population of leopard moths was smaller in 2006 and high in 2007. So, the biennial cropping of olive tree (Lavee, 2007; Hegazi et al., 2015) may have an effect on the flight phenology of ZP moth, i.e., the olive tree may be more suitable for larval growth of ZP moth during the "of-year" than during the "on-year". In both monitoring periods few females were caught by the light-pheromone traps in the monitoring areas. This may reflect the fact that ZP moths are extremely poor fliers. Results of this study provide evidence that some olive varieties (Hamed, Sennara and Toffahi) are susceptible varieties to ZP infestation. They were badly infested and insome plots, nearly every tree was infested or recovered from infestation. A consistent lower cumulative number of larval galleries and lower number of broken branches were observed on some other varieties, e.g., Shami, Akss and Dolcie. So loss of fruits on limbs that broke following the physical weakening by ZP larvae was minimum, compared to the susceptible varieties. On the latter, obvious damage such as broken or severely injured trunk and limbs were easy to recognize. Infestation severity, as measured by percentage of infested trees was significantly higher on susceptible trees compared with others. Consideration of planting pattern of olive varieties "crop- crop diversity" in intercropping appears to be a determinant factor for olive tree infestation by ZP and fruit yield production. A consistent higher cumulative number of active galleries was observed on Toffahi - Sennara or Sennara - Hamed varieties, i.e., susceptible - susceptible varieties. However, cropping pattern with ZP-resistant variety "e.g. Shami" as a companion crop with Toffahi, or Sennara showed significantly lower population density of ZP larvae "active galleries" on the susceptible crops. Barbosa et al. (2009), reported that specific plant association may decrease (Associational Resistance, AR) or increase (Associational Susceptibility, AS) the likelihood of detection by, and/or vulnerability to, herbivores. Experimental data on AR and AS mechanisms are lacking. Therefore, AR of Sahmi functional more as a repellent than as a depository or source for ZP moth. A significant effect on both varieties of cropping system $(P=0.01)$ on fruit yield was found. The Toffahi trees planted in strip intercropping with Sennara (another susceptible tree) showed significantly lower yield when compared to Toffahi planted with Shami. In terms of pest control, these cropping patterns rely on the fact that ZP moths recognize suitable olive trees either by sight or by smell and mixtures of susceptible and resistant varieties can be structured so as to confuse the pest. Neighboring vegetation can also influence the infestation severity within the field. For example, Dolcie or Kalamata is known as ZP-resistant trees, but the nearest strips to Toffahi trees (Plots 8 was heavily infested with ZP. Susceptible - Susceptible interplanted have been frequently attacked by ZP larvae.
The larval tunnels in the wood and girdling burrows under the bark are visible at the end of broken branches. Numerous partly broken branches with dead brown foliage hanging in tree crowns are characteristic of heavy infestation. This suggests that the susceptible variety, e.g., Toffahi is high quality host. Development (survival, growth) of artificially infested larvae (no-choice test) with olive shoots confirmed this fact. Our experiments demonstrate a rapid method to assess the suitability of olive trees to the xylophagous species. Similar method for ornamental trees was described by Bancroft et al. (2002). The unusual records of ZP larvae observed in 2009 and drastic reduction of emergence holes in 2010 suggest that the pest suffers huge mortalities in the field. Leaving the small ZP larvae the galleries formed in the bud axils and small branches to infest new plant parts may contribute in the larval mortality. The above results showed how important it is to consider with certain pests, e.g. ZP, the control of which is intended, in choosing olive varieties for founding an olive orchard with diverse varieties. Many varietal combinations are possible and each may have different effects on insect populations. The choice of susceptible as trap-crop; resistant as a companion crop for susceptible one, tall or short, early or late maturing, flowering or non-flowering companion crops can magnify these effects.

Our preliminary field study on surface wash and volatile collections in situ, analysed by GC and GC-MS, both showed that in terms of major peaks of released volatiles, the more resistant variety showed fewer and smaller peaks. We believe that varieties with less insect infestation are resistant due to allelochemics affecting pre- or post-landing host selection possibly habitat selection. Further studies are needed to reveal elements of the Associational Resistance

\section{ACKNOWLEDGEMENT}

This study has been carried out with financial support of Linneaus program "Insect Chemical Ecology, Ethology and Evolution (ICE3) and by SIDA/VR MENA Swedish Research Links funds. We gratefully acknowledge grower-collaborator Mr. M. Sheta for providing several research plots in his orchards and his co-workers for helping with field work. E.M.H. thanks the Alexander Von Humboldt Foundation for research donation used in this work.

\section{REFERENCES}

Abdel-Kawy AGM, El-Bishry MH, El-Kifi TAH (1992). Controlling the leopard moth borer, Zeuzera pyrina by three entomopathogenic nematode species in the field. Faculty of Agric. Bulletin, University of Cairo 43, 769-780. Aramborg Y (1983). In R Cavalloro and A Piavaux, eds CEC programme on integrated and biological control. p 103-110, Progress Report 1979/1981, Brussels - Luxembourg, pp 347.

Aramborg $Y$ 1983). In $R$ Cavalloro and A Piavaux, eds CEC 
programme on integrated and biological control. p 103-110, Progress Report 1979/1981, Brussels - Luxembourg, pp 347."

Avilla J, Bosh D (2001). Mass trapping and mating disruption for the control of leopard moth and apple clearwing moth. IOBC/WPRS Bulletin 24, 167-172.

Bancroft JS, Smith MT, Chaput EK, Tropp J (2002). Rapid test of the suitability of host-tree and the effects of larval history on Anoplophora glabripennis (Celeoptera: Cerambycidae). J. of the Kansas Entomological Society, 75(4), 308-316.

Barbosa P, Hines J, Kaplan I., Martinson H, Szczepaniec, Szendrei Z (2009). Associational resistance and associational susceptibility having right and wrong Neighbors. Annual Review of Ecology, 40, 120.

Bonnemaison L (1976). Enemigos animals de las plantas cultivadas y forestales. II OIKOS-TAU, SA Endiciones, Barcelona, Spain.

Carter DJ (1984). Pest Lepidoptera of Europe with special reference to the British Islands. Series Entomologica. Dr. W Junk Publishers, Dordrecht 31, 431.

Castellari PL (1986). Zeuzera pyrina L. (Lepidoptera; Cossidae): indagini biologiche eprove in campo sullattrattivita di miscele di componenti del feromone seesuale. Boll. 1st Ent "G Grandi", Univ Bologna 40, 239-270.

Feron J, Audemard H, Balachowsky AS (1966). Entomologie appliquée á l'agriculture, pp. 39-59. In A.S. Balachowsky [ed.], Masson, Paris 11-1, France.

Gatwick J (1992). Crop pests in the UK. p. 126-127. In "Collected Edition of Maff Leaflets" Chapman and Hall, London.

Hegazi EM, Khafagi WE, Konstantopoulou MA, Herz A, Raptopoulos D, Tawfic H, Abd El-Aziz GM, Abdel-Rahman SM, Atwa A, Essam A, Showeil S (2009). Efficient Mass-Trapping Method as an Alternative Tactic for Suppressing Populations of the Leopard Moth, (Lepidoptera: Cossidae). Annals of the Entomological Society of America, 102(5), 809-818.

Hegazi EM, Khafagi WE, Konstantopouulou MA, Schlyter F, Raptopoulos D, Showeil IS, Abd El-Rahman S, Atwa A, Ali SE, Tawfik H (2010). Suppression of Leopard moth (Lepidoptera: Cossidae) populations in olive trees in Egypt through mating disruption. Journal of Economic Entomology, 103 (5), 1621-1627.

Hegazi E, Shlyter F, Khafagic W, Atwad A, Agamy E, Konstantopoulou $M$ (2015). Population dynamics and economic losses caused by Zeuzera pyrina, a cryptic wood-borer moth, in an olive orchard, Egypt. Agricultural and Forest Entomology, 17: 9-19.

Hichman JM, Wratten SD (1996). Use of Phacelia tanacetifolia strips to enhance biological control of aphids by hoverfly larvae in cereal fields. Journal of Economic Entomology, 89, 832-840.

Howard LO, Chittenden FH (1916). The leopard moth: 1. Dangerous imported insect enemy of shade trees. USDA, Farmer's Bulletin, Washington, DC, 708.

Ismail II, Abou-Zeid NA, Abdallah FF (1992). Population dynamics of the leopard moth, Zeuzera pyrina L., and its control on olive trees in Egypt. Zeitschrift Fur Pflanzenkrankheiten Und Pflanzenschutz, 99, 519-524.

Katlabi H (1989). In pests and diseases of olive and apple trees in coastal areas. Proc. Workshop, Tartous, Syrian Arab Republic, p. 44-61. (in Arabic).

Lavee S (2007). Biennial bearing in olive (Olea europaeo) Annales Series Historia Naturalis., 17.

Myers JH (1988). Can a general hypothesis explain population cycles of forest Lepidoptera? Advances in Ecological Research, 18, 179-242.

Nashnosh IM, Baraka MM, Ismai W, Maayuf M (1993). Laboratory evaluation of natural and commercial preparations of entomopathogenic fungi and bacteria on the leopard moth, Zeuzera pyrina L. (Lepidoptera; Cossidae). Arab J. of Plant Protection, 11, 73-76.

Navon A (1977). Rearing of the leopard moth Zeuzera pyrina L. on an improved diet. Phytoparasitica, 5(1), 38-40.

Pasqualini E (1989). Technique di lotta biologica in sistemi di lotta integrate sulle pomacee. Inf Agrar Verona 45, 67-78

Pasqualini E, Antropoli A, Faccioli B, (1992). Attractant performance of a synthetic sex pheromone for Zeuzera pyrina L. (Lepidoptera; Cossidae). Bollettine della Istituto di Entomologia Guito Grandi della Universita degli Studi di Bologna, 46, 101-108.
Pasqualini E, Antropoli A, Faccioli G, Molfese M (1993). Zeuzera pyrina L. (Lepidoptera; Cossidae): Results of five year researches on sex attractant. Bulletin OILB/SROP 16, 189-194.

Pasqualini E, Civolani S, Vergnani S, Calzolari G (1996). I feromoni nella difesa da Zeuzera pyrina e Cossus cossus. L'inf Agr Verona 18, 69-75.

Pasqualini E, Natale D, Witzgall P, El-Sayed A.(1999) Zeuzera pyrina and Cossus cossus (Lepidoptera; Cossidae) control by pheromones: four years advances in Italy. IOBC wprs Bulletin 22, 115-124.

Rämert B, Lennartsson M, Davies G (2002). The use of mixed species cropping to manage pests and disease-theory and practice. In: Powell, J., et al. (Eds.), UK Organic Research 2002: Proceedings of the COR Conference, 26-28 March 2002, Aberystwyth, pp. 207-210.

Tadros AW, Revri R (2004). Olives, Olea europaea L. (Oleales: Oleacae) horticulture practices and integrated pest management (IPM). Olive Manual, pp. 1-39.

Thresh JM, Cooter RJ (2005). Strategies for controlling cassava mosaic virus disease in Africa. Plant Pathology, 54: 587-614.

Tremblay E (1986). Entomologia applicata, Vol. II Ed. Liguori, Napoli, pp. 344-350.

Trenbath BR (1993). Intercropping for the management of pests and diseases. Field Crops Res., 34: 381-405.

Theunissen J, Den Ouden H (1980). Effects of intercropping with Spergula arvensis on pests of Brussels sprouts. Entomologia Experimentalis et Applicata, 27, 260-268. 